\title{
Greves, dinamites e boicotes: galegos anarquistas no Rio de Janeiro
}

\author{
Érica Sarmiento da Silva \\ Universidade do Estado do Rio de Janeiro
}

Pelo paquete Arlanza seguiram ontem deportados para Portugal e Espanha mais sete indesejáveis dinamiteiros e perigosos anarquistas /.../.

Os que ontem seguiram barra fora chamam-se Alexandrino Valente Coutinho, José Gonçalves Brito, Manoel Barbosa, Abel Ribeiro dos Santos, João de Oliveira, Primitivo Ayrosa e Vicente de Dios Bello.

A exepção dos dois últimos, que são espanhóis, todos os outros são portugueses. ${ }^{1}$

Mês de março de 1921. Os jornais cariocas Gazeta de Notícias, Jornal do Brasil e $A$ Pátria divulgavam a notícia dos sete anarquistas expulsos do país, com diferentes posturas a respeito do tema. No navio Arlanza, viajavam Primitivo Ayrosa e Vicente de Deus Bello, o primeiro originário da província de Pontevedra e o segundo de A Coruña, na Galiza. Para eles, a imigração teve um ponto final que se resumiu em uma só palavra nos seus processos de expulsão: anarquistas.

A história desses imigrantes, que retomaremos nas páginas seguintes, faz parte de um contexto histórico-social que vivia o Brasil no começo do século XX. Nas três primeiras décadas da República, três correntes ideológicas se confrontaram para organizar a classe operária. Duas delas se propunham não apenas a esse objetivo, mas também ao de construir uma sociedade nova, igualitária, sem classes e sem exploração, sem Estado e sem dominação, a partir da supressão da sociedade capitalista e do Estado burguês. Eram as correntes anarquistas - em especial as vertentes anarco-sindicalista e socialista reformista. A terceira corrente organizatória, constituída pelos amarelos ou trabalhistas, lutava apenas por conquistas econômicas imediatas, por melhores condiçôes de vida e trabalho e aceitavam tacitamente uma posição de dependência em relação ao Estado. ${ }^{2}$ 
O anarco-sindicalismo, vertente do anarquismo que dominou a liderança do primeiro movimento operário brasileiro, recusava a luta política, propunha como estratégias de ação a luta econômica e ideológica e utilizava como tática a ação direta, a greve, o boicote, a sabotagem, os comícios e as diversas formas de manifestaçóes públicas. Nasceu em um ambiente de exclusão social, cercado de pobreza e de trabalhadores submergidos no mercado informal. Dessa maneira, propagou seus ideais libertários para além do mundo do trabalho, unindo não só operários, como também imigrantes desocupados e uma importante parcela da população que se sentia excluída de todo o processo de modernização da capital. O objetivo do sindicalismo revolucionário era fazer da luta incessante pelas reivindicações um meio de tornar insuportável o poderio do industrialismo e/ou do capitalismo, até fazê-lo estourar numa greve geral de caráter revolucionário e então proceder à transformação da sociedade.

O movimento anarquista do começo do século XX não foi exclusividade da sociedade brasileira. Outros países sul-americanos que receberam importantes fluxos migratórios de espanhóis e italianos, como o caso da Argentina, também tiveram seus ativistas anarquistas na mira das leis de residência e defesa social, que expulsavam qualquer estrangeiro indesejável. A imagem dos imigrantes era alterada segundo as mudanças políticas dos países receptores. $\mathrm{O}$ estrangeiro podia ser sinônimo de um agente da modernização e do progresso ou um elemento perturbador da ordem. Para o historiador argentino Fernando Devoto, para o caso da imigração na Argentina:

Al problema de cómo reconstruir una identidad nacional, sepultada por la heterogeneidad, venían a sumársele otras cuestiones. Primero, la emergencia de una problemática social con la aparición de una creciente conflictividad laboral y de una paralela violencia política alternativa, por parte de grupos activistas anarquistas que fácilmente eran identificados como otro resultado de la inmigración indiscriminada. ${ }^{3}$

No caso do Rio de Janeiro, segundo o historiador Boris Fausto, o processo não foi diferente do de São Paulo. ${ }^{4} \mathrm{Na}$ então Capital Federal brasileira, a estrutura social era mais complexa que na capital paulista. Ali se concentravam os setores sociais menos dependentes das classes agrárias, como a classe média, os militares e os universitários. A classe trabalhadora ocupava-se principalmente dos setores de serviços, tratados com uma consideração mínima por parte do Governo. As relações eram muito 
mais paternalistas entre os trabalhadores e seus patrōes e o próprio Governo. Já em São Paulo, a classe média girava em torno da burguesia do café e a maior presença de operários estrangeiros favorecia o anarquismo: o patrão e o Governo eram inimigos. Em termos gerais, pode-se atribuir a superioridade relativa do movimento operário de São Paulo sobre o Rio de Janeiro também ao fato de os italianos constituírem o maior grupo de estrangeiro da força de trabalho paulistana, enquanto os brasileiros e portugueses mais passivos constituírem o grosso da força de trabalho somente na Capital Federal. Dessa maneira, encontramos no Rio de Janeiro revoltas de caráter muito mais popular que especificamente operária.

A população brasileira, $80 \%$ da qual não tinha direito à participação política, estava mais que nunca atenta a todas as atuações políticas que pudessem afetar seu cotidiano. Sem mecanismos constitucionais que pudessem defendê-lo, o povo manifestava-se pelas ruas da cidade, através de protestas, quebra-quebra e algazarras. Uma das revoltas mais significativas do começo do século XX, no Rio de Janeiro, foi a Revolta da Vacina, no ano de 1904. O tumulto começou por culpa da arbitrariedade do governo carioca que queria erradicar a febre amarela à força. Como a população não respondia às campanhas institucionais, o governo decidiu entrar na casa dos cidadãos e vaciná-los à força, sem qualquer respeito à vida privada dos indivíduos. Os chefes de família sentiram-se desonrados com a presença de funcionários públicos que obrigavam suas filhas e esposas a se desnudarem diante de estranhos. A situação tornou-se insustentável e uma multidão fragmentada, composta por vários segmentos sociais da população, desde associações de trabalhadores até famílias ofendidas, começou a descontar a sua ira nos serviços públicos e nos representantes do governo. ${ }^{5}$

O descontentamento era geral. Ninguém era poupado pela violência policial. As denúncias de arbitrariedade não eram somente publicadas pela imprensa operária, também os jornais cariocas, das mais distintas tendências ideológicas, descreviam com detalhes reportagens que fotografavam graficamente a tensão vivida no cotidiano carioca:

Os Syrios moradores na Praça da República e suas imediações vão apresentar um protesto ao Dr. Chefe de polícia contra os abusos cometidos, ontem, à noite, pela força da cavalaria, ali postada, e que sem motivo algum disparou as suas carabinas contras as pessoas que se achavam nas janelas de suas casas. 
Ontem no bonde de "Fábrica" que sai do Largo de São Francisco às $5 \frac{1}{2}$ viajava um nosso companheiro que foi testemunha ocular da caçada humana feita pela polícia do Sr. Souza Aguiar no Campo de Sant Anna. “/.../ Naturalmente hoje o Sr. Comandante da Brigada há de ter dito ao Chefe do Estado que o povo é que provoca a polícia". ${ }^{6}$

As revoltas estavam compostas por um fragmentado setor popular carioca, formado por uma enorme população de subempregados e com um setor do artesanato, recém-saído da escravidão, e que não tinha nenhuma tradição de organização e luta. É dentro deste panorama que devemos tentar compreender a atuação dos galegos no movimento anarquista ou no movimento operário. Ser anarquista, socialista ou comunista podia ter dois significados: aqueles que eram militantes e eram conscientes das doutrinas que propagavam; ou aqueles trabalhadores que simplesmente se misturavam com as ideologias de esquerda, não porque fossem conhecedores das teorias, mas porque se sentiam identificados com o programa de melhorias sociais reivindicados por elas.

Segundo Lená Menezes, o movimento anarquista, no Rio de Janeiro, manifestou-se em três planos, em um primeiro, ele se caracterizou como um movimento de idéias, valores e comportamentos, que atingiu os segmentos médios da população, principalmente os mais intelectualizados. No segundo plano, definiu-se como um movimento de trabalhadores que atingiu os setores profissionais nos quais os estrangeiros se faziam muito presentes, com realce para o comércio e para o setor oficinal. Nesse nível específico, ele fundiu-se ao movimento operário, tornado o anarcosindicalismo uma vertente de grande expressão no movimento. Em um terceiro plano, ele irradiou-se para o conjunto dos excluídos, postos à margem do mercado formal de trabalho. Nesta dimensão, dissolveu-se nos movimentos de contestação de rua que pontilharam o cotidiano da cidade, caracterizados pelos quebra-quebras generalizados de configuração pluriclassista. $^{7}$

Acreditamos que a maioria dos galegos fez parte do segundo e terceiro momentos do anarquismo, através de associações como o Centro Cosmopolita (setor da hotelaria) ou a União dos Empregados de Padaria. O pequeno comércio, a classe média e as classes operárias começaram a se fortalecer numericamente e tomar consciência da situação de pobreza em que estavam envolvidas. $\mathrm{O}$ alto custo de vida, a falta de moradia, a violência policial e o desalojamento resultante da destruição de parte das casas da zona central do Rio de Janeiro desencadearam uma série de revoltas 
populares que uniu diversos segmentos que antes não haviam sido afetados economicamente e moralmente pelas novas reformas republicanas.

No caso dos galegos, temos que analisar com muita cautela. A comunidade galega do Rio de Janeiro ocupava o setor terciário e o da hotelaria e seus trabalhadores se dividiam basicamente entre dependentes de comércio e garçons. Se considerarmos os galegos como um contingente migratório flutuante, ou seja, que viam o Brasil como um meio de vida temporário até conseguirem juntar recursos econômicos suficientes para retornar à sua terra de origem, é compreensível que muitos imigrantes não quisessem se envolver com questões políticas. Muitos autores relacionados com o movimento operário no Brasil, em especial no Rio de Janeiro, identificavam o objetivo do retorno com a debilidade do movimento operário. Um sindicalismo forte requer uma força de trabalho relativamente estável, que veja sua participação como um meio necessário de melhorar sua posição econômica:

O imigrante médio teve pouco contato com o trabalho organizado em sua terra natal. De certa forma, o próprio ato de migrar revelava uma rejeição ao envolvimento com as lutas operárias que poderiam melhorar sua existência. O imigrante sonhava que o trabalho em terra estranha o levantaria acima da classe trabalhadora. Enquanto ele via o Brasil como lar temporário, relutava em participar dum movimento que poderia causar-lhe a perda do emprego, a sua prisão, e o que seria pior, a deportação para seu país de origem, onde retornaria para a miséria que sempre desejara abandonar, correndo o risco de ser preso como agitador perigoso. ${ }^{8}$

A forma de organização de trabalho dos galegos estava baseada em laços de parentesco. Os primeiros trabalhos giravam em torno das indicações recomendadas por patrícios e à medida que o imigrante melhorava suas economias, passava-se a outro estágio, que era o de comprar um pequeno negócio, que, por sua vez, também podia ser em sociedade com outros galegos. Era uma situação diferente a do operário, que não tinha as mesmas possibilidades de ascensão que proporcionava o comércio. Uma vez que se tornavam proprietários, esses galegos repetiam as mesmas experiências que os primeiros patrícios, empregando ou indicando novos conterrâneos que chegavam. Essa relação de compromisso e afetividade fechava um círculo que era difícil de romper. Envolver-se com os movimentos operários significava apoiar aos trabalhadores de todas as nacionalidades, cortar relaçôes com patrões que podiam ser seus próprios parentes ou vizinhos e caminhar do lado contrário a essa ordem estabelecida pela comunidade galega. Era uma mobilidade sócio-profissional, que 
passava de empregado a patrão, e uma vez que se tornavam donos do seu próprio negócio também a posição política e ideológica mudava de postura.

Através das entrevistas, das fontes orais, conseguimos resgatar uma parte da história da imigração, utilizando a experiência dos próprios protagonistas. Os imigrantes mais antigos lembram desse tempo de agitaçôes e de alguns dos seus colegas que encabeçaram greves:

O Agapito Cabalar, que era lá de perto da aldeia de Covelo (A Lama - Pontevedra), que morreu com 97 anos, era um dos cabeças das greves. Tinha muito naquele tempo, depois alguns entraram no comércio, aí deixaram de ser comunistas. Conheci donos de restaurantes, de hotel, que não queria que falasse disso porque eles melhoravam um pouquinho de vida e já não eram mais comunistas, tiravam o corpo fora. ${ }^{9}$

Tinha um senhor que se chamava Diegues, que era um intelectual, muito bem preparado, que chegou a ser presidente do Sindicato de Hotéis no Rio de Janeiro, um cargo que era proibido para estrangeiros, mas ele era nacionalizado. ${ }^{10}$

Eu nunca participei de política. Preferi me manter fora disso. A constituição não permite que estrangeiros participem. Se a pessoa se mete na política do país dos outros está sujeito a ser expulso ou vai para cadeia. Havia muitos, inclusive eu soube, entendeu? Depois acabou sendo donos de restaurantes. Um homem muito rico chegou a liderar uma greve, entrar num quartel general... a greve dos garçons naquela época era com muitos intelectuais e era muito pela esquerda e a dos barbeiros também. Eram classes que eram muito ativas. Tinham muitos que eu conheci, depois foram presos. Mas os que já vinham na década de 50 não se metiam mais nisso. Já tinham outros objetivos. Nosso caso era triunfar, mas de política nada, isso não leva nada. Só aquele que quer tirar partido da política, que vai se fazer com a política, esse sim. ${ }^{11}$

Era certo que uma parte da comunidade galega não queria envolver-se com questôes políticas, mas não podemos ignorar as referências bibliográficas, as fontes orais e os processos de expulsão que mencionam a participação de galegos nas greves e distúrbios que fizeram parte do cenário carioca. Havia desde líderes sindicais, ativistas anarquistas, como simplesmente assalariados que se uniam às associações da sua classe para melhorar suas condições de vida. O próprio Centro Galego cedeu suas instalações para celebrar o Primeiro Congresso Operário Brasileiro, no ano de 1906, e foi fechado no ano de 1940 por dissidências políticas entre seus membros, a maioria de ideologias de esquerda. Nas associaçóes relacionadas ao setor de serviços (trabalhadores portuários, ferroviários, 
construção civil), por exemplo, apesar dos seus membros estarem compostos mais pela população nativa e por imigrantes portugueses, na lista de fundadores aparece mais de um espanhol encabeçando a lista. $\mathrm{Na}$ União dos Operários Estivadores, fundada em 1903, 40\% dos seus associados eram estrangeiros oriundos de Portugal, Cabo Verde, Itália, Espanha, França e Inglaterra. O resto era formado por brasileiros (entre os quais muitos negros). Entre 1903 e 1905, estavam inscritos nesse sindicato, 503 brasileiros, 213 portugueses, 42 espanhóis, 17 ingleses e italianos e 18 sócios de outras nacionalidades. ${ }^{12}$ Nos livros de registro do sindicato dessa instituição, na lista de fundadores, aparecem vários portugueses e espanhóis, como José Sarmiento de Castilho, e uma foto de outro espanhol, possivelmente galego, chamado José Conde, que junto com seu irmão, Santiago Conde, ajudaram a fundar a União dos Operários Estivadores. A família Conde, desde a época da fundação, teve sempre um membro associado ao sindicato. ${ }^{13}$

Na greve geral de 1917, também estiveram envolvidos diversos espanhóis que representavam o setor mais importante do operariado carioca: o das fábricas de tecido. Mais concretamente, no bairro da Gávea, onde se localizava uma das fábricas, foram presos 78 anarquistas, dentre eles vários espanhóis, suspeitos de empregarem bombas e armas. Segundo conta Forster Dulles, sobre um episódio relacionado com o anarquismo no Rio de Janeiro:

A 22 de novembro /.../ os jornais estamparam manchetes sensacionalistas em que se relatava a ação enérgica da polícia, ao desbaratar um atentado inominável dos anarquistas que planejavam dinamitar as represas de Ribeirão das Lajes, para privar a cidade de luz, força e serviços de bondes /.../ As notícias dessa quase calamidade se fizeram acompanhar da revelação de que nada menos do que 78 anarquistas tinham sido presos de 18 a 21 de novembro. Estavam entre eles diversos espanhóis suspeitos e empregados em fábrica na Gávea, grevistas que tentaram reunir-se num matagal de Bangu, elementos encontrados num galpão com documentos subversivos e indivíduos apreendidos portando bombas ou armas. Dizia-se que os anarquistas estrangeiros seriam deportados e que os nacionais seriam enviados para a ilha Fernando de Noronha, ao longo da costa nordestina. ${ }^{14}$

Seguramente, esses espanhóis ou galegos que eram líderes de sindicatos contribuíram principalmente com os seus conhecimentos, a sua experiência e com o seu grau de instrução, superior à da maioria da população brasileira. A sua condição profissional contrastava com a sua 
participação nos sindicatos. No dia-a-dia eram empregados de hotéis, de pequenos comércios ou operários. Esse foi o caso de Antonio Fernández, natural de Porriño ( província de Pontevedra), sapateiro, que chegou ao Rio de Janeiro no ano de 1912, com a idade de 21 anos. Era empregado de uma casa de calçados na Rua Senhor dos Passos, no Centro da cidade. Fora do seu ambiente de trabalho era associado da Aliança dos Operários em Calçado e Classes Anexas, conhecido por ser um hábil orador, além de ser delegado dos sapateiros junto à federação das diversas classes, tendo sido designado em mandato conferido por diversas assembléias. ${ }^{15}$

No termo de declaraçôes do seu processo de expulsão, Antonio Fernández não nega a sua condição de comunista, mas alega que:

... junto com a federação pugna somente pelos seus interesses econômicos e sociais, de acordo com o programa econômico da classe, sem intervenção de qualquer orientação política e credo religioso ou filosófico /.../ que o depoente é individualmente contrário à propriedade privada por nela encontrar um princípio de desigualdade econômico-social, defendendo as doutrinas comunistas, por achar que elas equipararão a igualdade de direito entre os indivíduos. ${ }^{16}$

O que ele queria demonstrar era que acreditava nas idéias comunistas, mas sempre através das palavras, não se utilizando da violência. Escrevia em alguns jornais como Spartacus e $A$ Razão e dava palestras a trabalhadores com o fim de propagar suas idéias. De fato, a sua primeira detenção, no ano de 1918, foi unicamente por "medida de segurança pública, por ser um anarquista confesso". No seu processo de expulsão, uma das testemunhas, chamada Prisco Salgado, um agente de Corpo de Segurança Pública, frisou o perigo desse elemento para as classes trabalhadoras, porque era um eloqüente orador, presente em quase todos os meetings. A mesma testemunha havia escutado o discurso de Antonio Fernández, no Primeiro de Maio, em uma manifestação na Praça Mauá, onde o acusado utilizava de uma "linguagem violenta", aconselhando o povo à implantação do regime anarquista. Segundo o depoimento da acusação, Antonio Fernández também havia proferido o mesmo discurso nas sacadas da Sociedade dos Marceneiros, sociedade cujo fundador também era um espanhol chamado Manuel Pérez Fernández, expulso em 1919. Sem dúvida, Antonio Fernández era um indivíduo "perigoso" para as elites brasileiras: estrangeiro, bom orador e carismático. Nem sequer o investigador policial omitiu suas qualidades de líder, qualidades essas que podiam perturbar a ordem pública. A segunda testemunha, um 
advogado, que se referiu a si mesmo como um "interessado da questão social”, verificou que

vários elementos, muitos dos quais estranhos às classes operárias, estrangeiros na sua maioria, vem fazendo de alguns anos a esta parte uma campanha desenfreada das idéias, que dizem libertárias, propagando o comunismo por meio dos discursos nas sedes das associações operárias. ${ }^{17}$

Apesar da participação como líderes em diferentes sindicatos, havia duas associações, muito ativas no começo do século XX, onde acreditamos que poderia estar afiliados a maior parte dos trabalhadores galegos: o Centro Cosmopolita e a União dos Empregados de Padaria. Os estudos sobre o movimento operário no Rio de Janeiro confirmam a presença dos imigrantes espanhóis em determinados tipos de sindicatos, tal como afirma Sheldon Maram:

Os imigrantes dominavam os sindicatos mais poderosos e mais influentes da capital federal, incluindo o sindicato dos trabalhadores em construção civil, o Centro Cosmopolita e a organização dos trabalhadores de hotéis, bares e restaurantes. Esses dois sindicatos, cujos membros provinham, principalmente, de Portugal e Espanha, estavam à testa do movimento operário, em sua fase mais ativa, 1917 a 1920, liderando greves e auxiliando a organizar os trabalhadores descolocados de seus sindicatos. ${ }^{18}$

Nas greves que irromperam no Rio de Janeiro, na segunda década do passado século, o Centro Cosmopolita participou ativamente. Formado por trabalhadores do setor da hotelaria, era considerado um forte reduto de anarquistas e seus associados foram perseguidos durante várias décadas pela polícia carioca. Em janeiro de 1912, os cozinheiros do Centro reivindicaram a redução da sua jornada para 12 horas e também o descanso semanal. No mesmo ano, 12 padeiros foram presos acusados pelos seus patrôes. Três anos depois, em 1915, o Centro Cosmopolita é o responsável por decretar a parede, sendo apoiado por outras categorias profissionais, como os carroceiros, choferes e cocheiros. Em abril de 1917, ano da Greve Geral, eles pregam a greve porque os negociantes não queriam fechar as suas lojas às 20 horas, segundo o regulamento da Prefeitura. A greve se estende a outras categorias, entre elas as dos operários de fabricação de calçados e a dos operários dos barcos da Cantareira. ${ }^{19}$ No ano de 1917, o chefe de polícia do Rio de Janeiro, Aurelino Leal, resolveu fechar o Centro Cosmopolita por terem recebido a tiros a Força Pública. Executada a ordem, Aurelino Leal dirigiu ao público a seguinte explicação: os operários, que em sua maior parte eram estrangeiros das sacadas do "malafamado" Centro Cosmopolita alvejaram a pedra e a balas as autoridades. ${ }^{20}$ 
Os garçons, cozinheiros, lavadores de pratos, profissões exercidas por muitos galegos, agüentavam árduas jornadas de trabalho, sem direito a descanso ou férias remuneradas. Alguns imigrantes lembram os garçons como

Uma classe muito política, eles se metiam na política nacional e no tempo de Getúlio Vargas o governo mandava eles embora. Muitos deles foram presos. Naquele tempo, por qualquer coisa que se falava eram já anarquistas. Eu nem sabia o que era anarquismo. Se alguém gritava, era considerado um anarquista. $\mathrm{O}$ anarquismo é uma coisa fina, não é nada disso. Eu sei que havia esse sindicato de hotelaria e tinha vários outros. ${ }^{21}$

Os garçons estavam fortemente organizados e apesar do Centro Cosmopolita ser o mais representativo, havia outras como a União Internacional dos Garçons, fundada no dia 20 de agosto de 1919. Em um dos jornais cariocas saía a seguinte notícia com o título Uniāo Internacional dos Garçons:

Há sociedades com programas brilhantes, que impõe desde logo o seu prestígio nas camadas populares.

Está neste caso um conceituado núcleo formado por um punhado de moços fortes, empregados e "maitres" de nossos principais hotéis e que se propóe a defesa da operosa classe. ${ }^{22}$

Dentre os membros da diretoria encontramos dois vice-presidentes com sobrenomes de origem galega: Julio Durán- gerente no Club dos políticos- e Antonio Cerdeira- garçom no Palácio Guanabara. Mais uma vez encontramos lideranças galegas dentro de sindicatos. Esses dois imigrantes trabalhavam ou participavam do comércio e de associações brasileiras, o que demonstra que uma parte da comunidade galega, entre eles os que se nacionalizaram brasileiros e/ou os que constituíram família no país, resolveram não regressar à Galiza e estavam dispostos a assumir as conseqüências de um processo de expulsão ou o encarceramento em nome das causas da sua classe.

A perseguição policial chegou à casa 12 da Rua do Rezende, $n^{\circ} 113$. Entre 22 e 23 horas do dia 20 de fevereiro de 1930, os investigadores entraram de surpresa no local e detiveram vários elementos filiados ao Centro Cosmopolita.

Tendo esta Secção sabido que hontem, ás 22 horas, compareceriam á reuniāo de núcleos na residência do cozinheiro Amaro Ribeiro, á rua do Rezende, no 113 , casa 12 , vários elementos filiados ao Centro Cosmopolita obedientes á orientação do Partido Comunista, destacou para surprehendel-os e atrazel-os á esta Repartição uma turma de investigadores. ${ }^{23}$ 
Os processos de expulsão de José Thomé Martins e José Quintáns Antelo nos levaram até a pista de alguns dos garçons galegos considerados "elementos perniciosos e perigosos para a segurança da República”. Além de José Martins, encontravam-se mais 14 indivíduos reunidos na casa e alguns deles, ainda que não aparecessem as suas nacionalidades, constatamos pelos sobrenomes que eram de origem galega ou espanhola, como Francisco Vilar, Salvador Vivas Cabanas, Feliciano Estevez Fernández e Antonio Núñez Marín.

Os membros do Centro Cosmopolita já estavam taxados como indivíduos comunistas e estavam fortemente vigiados pelos detetives do Gabinete de Identificação e Estatística Criminal do Rio de Janeiro que:

empenhados na repressão ao anarquismo e outras formas attentorias de organização política do país /.../ traz em constante vigilância os indivíduos que se revelam capazes de provocar actos de que resulte alteração da ordem pública; que sendo muitos os indivíduos desta espécie, principalmente os comunistas, a estes não perdem de vista. ${ }^{24}$

José Thomé Martins e José Quintáns Antelo foram algumas das vítimas $\mathrm{da}$ "caça às bruxas" da polícia carioca. Dois jovens garçons, expulsos antes de completar os 30 anos e sem direito a nenhuma defesa. Nos dois processos, as únicas testemunhas de acusação são os próprios investigadores policiais e as testemunhas de defesa não existem ou, pelo menos, não aparecem na documentação. A única defesa que eles tiveram foram as suas próprias palavras, alegando não serem comunistas e de que o objetivo da reunião era unicamente a defesa dos interesses da sua classe, como o aumento de salários e o descanso semanal. Entretanto, de nada serviram seus depoimentos. Os dois investigadores que testificaram alegaram que os acusados:

faziam apologia ao coletivismo tramando contra nossa organização social, que esses comunistas portavam avulsos revolucionários que davam vivas a partidos comunistas e á Internacional; que os comunistas eram já conhecidos da polícia.$^{25}$

Não foram os únicos sócios do Centro Cosmopolita expulsos do país. Outro galego, Nicolau Parada, foi preso várias vezes e para escapar da polícia carioca buscou refúgio no estado de São Paulo, onde ingressou na União dos Empregados em Café. Em 1924 foi preso e deportado sem julgamento, condenado para o campo de concentração do Oiapoque onde acabou morrendo de malária. ${ }^{26}$

Os trabalhadores estrangeiros que participaram nos movimentos operários eram, na maioria das vezes, indivíduos que residiam há muito 
tempo no país. Sheldom Leslie Maram $^{27}$ constatou que 93\% dos líderes sindicais estrangeiros (até o ano de 1917) vieram para o Brasil crianças ou já tinham 20 anos ou mais de residência, ou moravam no país há mais de 5 anos. Por sua vez, os processos de expulsão quase não mencionam o tempo de residência dos deportados, porque quanto mais se omitiam os anos de imigração, melhor para as autoridades, que reforçavam a causa do governo junto ao Supremo Tribunal Federal no julgamento dos apelos de revogação de expulsão. Quanto menos dados acerca da vida do imigrante, mais aumentavam as vantagens da polícia para obscurecer o seu passado. No caso dos dois galegos, tanto José Quintáns Antelo como José Thomé Martins, eles chegaram ao Rio de Janeiro com apenas 16 anos de idade e viveram na cidade durante mais de 5 anos. A idade e o tempo de permanência influíam na atitude do trabalhador. Depois de anos residindo em outro país, alguns indivíduos podiam considerar o Brasil como a sua morada definitiva, podiam estar mais adaptados e, por isso, havia maior possibilidade de se envolverem com as questóes do proletariado nacional.

Até o ano de 1912, os cidadãos com dois ou mais anos de residência estavam isentos de expulsão, assim como as esposas e filhos de brasileiros ou viúvas com filhos nascidos no Brasil. Entretanto, com as greves que começaram a eclodir a partir de 1912 e com uma classe trabalhadora mais numerosa e cansada das crises econômicas que assolavam o país, as autoridades passaram a denegar pedidos de hábeas corpus e a declarar leis inconstitucionais que já não protegiam os estrangeiros. As decisões variaram de acordo com as pressões políticas e sociais do momento. Alguns casos deixavam em evidência o não cumprimento das leis, como o imigrante espanhol Everardo Dias, que apesar de haver chegado ao Brasil ainda criança e estar naturalizado, não se livrou da expulsão, saindo do país junto com outros 23 estrangeiros no ano 1920. Edgar Rodrigues (1994-1998), nos quatro volumes do livro Companheiros, exemplifica vários casos de anarquistas que estavam naturalizados e outros com filhos brasileiros. O caso de Manuel Perdigão Saavedra, operário na cidade de Santos, é bastante ilustrativo. Foi expulso no ano de 1919 por ser anarquista. Quando chegou na Espanha, as autoridades espanholas não o aceitaram, porque desconhecia seu local de nascimento e o mandou de volta para o Brasil. ${ }^{28}$ Encontramos o processo de expulsão de Manuel Perdigão Saavedra, que na realidade, segundo a declaração da mãe do acusado, se chamava João Perdigão Guitérrez e havia nascido nas Ilhas Canárias e que "seu filho desde que veio da Espanha, em menino, nunca mais saiu desta cidade". ${ }^{29}$ 
Outra preocupação constante da polícia em relação aos estrangeiros e os movimentos operários era o emprego das dinamites. Algumas associações anarco-sindicalistas como a União dos Empregados de Padaria ou a incitavam aos trabalhadores à luta violenta, utilizando a Propaganda pelo Ato. Apesar de serem minoritárias dentro do movimento anarquista, essas associações espalharam o terrorismo pela cidade e acabou gerando um clima de tensão entre as autoridades brasileiras e outros sindicatos que eram contrários a essa prática. Foi a desculpa perfeita para que a imprensa e a polícia considerassem a todos os sindicalistas como perigosos terroristas.

Na capital brasileira, a exemplo do já sucedido no restante do mundo, foram as bombas o principal argumento a sustentar a propaganda antianarquista, tornando-se a principal justificativa no encaminhamento da repressão sobre todo o movimento anarquista, e para além dele, sobre todo o movimento operário. ${ }^{30}$

Os padeiros, no começo do século XX, foram uma das classes trabalhadoras que se destacaram pela violência de rua e pelas bombas que distribuíram pela cidade. ${ }^{31}$ Tudo começou com alguns escravos e homens livres que trabalhavam em padarias do Rio de Janeiro e resolveram organizar o Bloco de Combate dos Empregados de Padaria, cujo lema era "Pelo Pão e pela Liberdade". O seu líder, João de Mattos, chegou no Rio no ano de 1878, depois de haver tido seus primeiros contatos com cativos que trabalhavam nas padarias de Santos e São Paulo. Dizia "que eles eram a única classe que tinha a facilidade de propagar as idéias antiescravocratas e de insinuar os escravos à rebeldia por todos os meios". ${ }^{32}$ A violência utilizada pelos padeiros era a resposta de uma situação insustentável provocada pela escravidão e pelas árduas jornadas de trabalho:

Durante a madrugada, depois de preparar a massa do pão e vigiar o forno, os padeiros - que até 1850 eram principalmente escravos africanos- percorriam as ruas da cidade, parando de porta em porta para entregar os 'pãezinhos' ainda quentes, que carregavam em grandes sacos presos às costas. Era um trabalho que durava horas seguidas, atravessava dia e noite, tanto nas ruas como, quase sempre, em estabelecimentos mal iluminados e sujos, e em exposição constante às altas temperaturas do forno e à umidade. ${ }^{33}$

O mercado das padarias foi abrindo espaço entre portugueses e espanhóis/galegos que chegavam no século XIX. Os padeiros, considerados como um dos segmentos mais radicais no seio do movimento operário, respondiam à violência com a violência e eram conhecidos pelas autoridades e pela imprensa como incitadores de greves, violentos 
agitadores e adeptos ao emprego da dinamite e à destruição de padarias e comércios.

O caso de Primitivo Ayrosa, o padeiro expulso junto com o outro galego, Vicente de Deus Belo, e mais cinco portugueses "dinamiteiros", os quais mencionamos no início desse artigo, deixou uma parte da sua história nos processos de expulsão. Como outros companheiros galegos que participaram em sindicatos cariocas, ele era temido pela polícia por ser um agitador de grande influência entre os outros trabalhadores. Nas documentações anexas ao processo, constavam 10 detenções entre os anos de 1917 e 1921, chegando, inclusive, a ser preso duas vezes no mesmo mês. As testemunhas de acusação, formadas por dois investigadores policiais e um comerciante, destacaram a participação de Primitivo Ayrosa na União dos Empregados em Padaria e afirmaram

ser o acusado agitador de grande influência na classe dos padeiros, que tem levado a diversas greves, usando da violência quando seu apelo não é atendido por algum trabalhador padeiro. Depredações, desobediência às leis e autoridades, têm sido aconselhados pelo acusado na propaganda anarquista que faz nas associações. ${ }^{34}$

A defesa, como na maioria dos casos de expulsão por anarquismo, foram as próprias palavras do acusado, que confirmou pertencer à União dos Empregados de Padaria, mas que não participava de greves e nem tinha nenhuma ideologia política. Para a polícia, entretanto, bastava com as provas testemunhais e o ofício que demonstrava as inúmeras vezes que Primitivo Ayrosa havia sido detido. Ademais, o simples fato de pertencer a uma associação já conhecida pela sua trajetória violenta era confessar o próprio crime.

No conjunto total dos processos de expulsão, os portugueses e espanhóis (quase a metade originária da Galiza) estiveram à ordem do dia. Lená Medeiros de Menezes, numa amostra de 74 anarquistas processados entre 1917 e 1930, destaca a presença de 47 portugueses e 20 espanhóis, um importante foco de irradiação anarquista, que segundo constatou a autora, vinha de zonas rurais portuguesas e da Galiza. ${ }^{35}$ Assim demonstra o processo que analisamos do português Sebastiāo Lourenço, um padeiro de 33 anos, expulso um ano antes de Primitivo Ayrosa, em 1920. Foi acusado de organizar várias greves por diversas ruas do Rio de Janeiro e de organizar um complot para dinamitar as padarias, além de estar implicado em um atentado contra uma padaria chamada Avenida, localizada à Avenida Salvador de Sá. O seu ex-patrão, também português e dono de uma padaria, 
foi umas das testemunhas do processo, acusando Sebastiāo Lourenço de ser um empregado que sempre "desorganizava o trabalho". ${ }^{36}$

Curiosamente, Sebastião Lourenço era analfabeto. Foi o que ele mesmo declarou e também o investigador da polícia encarregado de declarar no processo. Dizia do acusado que:

embora não sabendo ler e escrever, é adepto fervoroso das idéias revolucionárias, e, na sua ignorância, tem aconselhado o ataque às famílias, à propriedade, à transformação da sociedade, afirmando o mesmo que será capaz, e efetivamente o é, de iniciar o movimento de saque à cidade, empregando bombas com elementos de destruição; que sendo dinamitada a padaria da Avenida Salvador de Sá, no 69, o declarante e os dois companheiros, que já prestaram declarações, depois de muitas indagaçôes chegara à conclusão de que o autor do atentado fora o acusado presente. ${ }^{37}$

Os empregados de padaria, ramo predominantemente português, estavam organizados na União dos empregados de padaria. Portugueses e galegos se organizaram através desse sindicato e, no século XX, muitos deles receberiam a resposta das autoridades brasileiras em forma de expulsão. Se existia uma associação ligada a esse tipo de comércio e que estava organizada a ponto de preocupar as autoridades cariocas da época é porque havia uma quantidade significativa de imigrantes exercendo essa profissão desde antes de iniciar as expulsões nas primeiras décadas do século XX. Os padeiros viram que, numericamente e/ou representativamente, eram capazes de se unirem e formarem uma associação que tivesse composta somente por trabalhadores desse ramo.

No século XX, aparecem empregados de padaria expulsos do país, acusados de anarquismo e de liderar movimentos trabalhistas, como foi o caso já citado de Sebastião Lourenço, acusado pelo governo, em 1920, de "pertencer a um complot que se tem encarregado de dinamitar as padarias desta capital", além de "achar-se implicado no atentado contra a padaria "Avenida”, sita à Avenida Salvador de Sá, 69."38 Não só estavam implicados em associações como também reagiam, pacífica ou violentamente, contra aqueles que prejudicavam seus interesses e exploravam o seu setor. Esse português foi acusado pelo ex-patrão de liderar uma greve dos empregados de padarias nas ruas Catumbi, Lavradio, Frei Caneca e São Cristóvão.

Nesse clima de terror foi como os jornais cariocas deram a notícia da expulsão dos sete estrangeiros, cinco portugueses e dois galegos, os "dinamiteiros" que foram expulsos no vapor Arlanza no dia 23 de março de 1921. Alexandrino Valente Coutinho, Manuel Barbosa, João Oliveira, 
Abel Ribeiro dos Santos, José Gonçalves de Brito, de nacionalidade portuguesa, e Primitivo Ayrosa e Vicente de Deus Bello, galegos, tiveram as suas fotografias estampadas na imprensa carioca. O Jornal do Brasil do dia 24 de março de 1921, favorável à expulsão dos sete estrangeiros, intitula a sua notícia, na página 9, como "A campanha contra os anarquistas". Argumenta que os indivíduos são perigosos porque estão envolvidos direta e indiretamente com os últimos atentados que ocorreram no Rio de Janeiro.

Alexandrino Valente Coutinho foi responsável pela explosão de bombas em diversos estabelecimentos comerciais da cidade, incluindo o Clube Naval, e que, posteriormente, foi pego em flagrante na sua residência, onde tinha uma fábrica de explosivos. Esse português confessou ser fabricante de petardos para a União dos Empregados em Padaria. O segundo, Manuel Barbosa, era padeiro e residia na Rua Senador Pompeu (localidade onde residiram vários galegos) e foi encontrado, segundo o periódico, com uma grande bomba revestida de folha de zinco e com dois quilos de explosivos, destinados a explodir navio do Lloyd Brasileiro. $\mathrm{O}$ petardo fora entregue por Alexandrino Valente Coutinho, que também o havia fabricado. João de Oliveira, o terceiro, foi um dos dinamiteiros de uma casa de construção. Abel Ribeiro, outro empregado de padaria, confessou à polícia que foi o autor do atentado contra a padaria Nova Central, localizada no subúrbio carioca. O quinto português, José Gonçalves de Brito, era marítimo e foi um dos fomentadores da greve dos carvoeiros e também participante em uma das greves dos marítimos. Quanto aos galegos, Primitivo Ayrosa e Vicente de Deus Belo, o jornal unicamente noticia que:

eram propagandistas do anarquismo, tendo o primeiro declarado ao cônsul de Espanha, que o foi ver na Repartição Central da Polícia que, embora não tendo cometido nenhum atentado, era anarquista, pelo que fazia muito bem a polícia em expulsá-lo. ${ }^{39}$

Que Primitivo Ayrosa era anarquista nenhum jornal o negava, mas dizer que estava conforme a sua expulsão era um argumento difícil de acreditar. Muitos deles tinham esposas e filhos brasileiros e já estavam mais que afincados na sociedade carioca. Dessa maneira, descreve ironicamente na coluna Bilhete, um dos mais importantes jornalistas da época, João do Rio, no jornal $A$ Pátria:

Pelas fotografias dos temíveis anarquistas, descobrirá v. um bando de rapazes sem nada de dinamiteiros. Lendo-lhes a breve história, saberá que são moços padeiros, alguns casados e com filhos, expulsos porque entendem a polícia considerá-los criminosos./.../ 
Havia, por exemplo, em Inhaúma, um pobre padeiro casado e pai de vários filhos. Um rapaz de 26 anos, casado e pai, parece que deve ser o modelo da ordem. Um belo dia a polícia (...) noticiou aos quatro ventos que o padeiro de Inhaúma tinha uma fábrica de petardos! A mulher e os filhos do padeiro também eram bolchevicks e assim foram expulsos! ${ }^{40}$

Segundo o jornalista, não houve nenhuma prova contra os estrangeiros expulsos e que além da polícia querer acabar com a imigração portuguesa, também perseguiam a espanhóis, "espanhóis da Galiza"- conta João do Rio- cujo único crime horrendo (no caso de Primitivo Ayrosa) era de ser o orador oficial da Sociedade dos Padeiros. A violência das autoridades brasileiras se estendia aos familiares dos anarquistas, atuando contra as leis que proibiam a expulsão dos filhos dos imigrantes nascidos no Brasil. Muitos estrangeiros eram desaparecidos sem deixar rastro. $\mathrm{O}$ nome de Primitivo Ayrosa, um mês antes da sua expulsão, apareceu numa notícia intitulada "Mais trabalhadores nacionais e estrangeiros desaparecidos", onde há uma lista de vários indivíduos presos e que posteriormente haviam desaparecido da delegacia. ${ }^{41} \mathrm{O}$ mesmo jornal, no dia 18 de fevereiro de 1921, denuncia a polícia e a imprensa carioca por fazer uma campanha contra a violência dos anarquistas sem haver demonstrado com provas contundentes a existência das dinamites:

Para nós, até que prove o contrário, a autoria das bombas está na polícia, no desejo de estabelecer o pânico e o poder, a vontade de perseguir operários, irritar e torturar as classes desprotegidas. Há seis meses dizemos isso. Há seis meses a polícia tem prendido e tornado a prender mais de mil criaturas acusadas de anarquismo, sem poder provar que elas sejam senão gente de trabalho. ${ }^{42}$

A culpabilidade dos estrangeiros pela divulgação das idéias anarquistas e a sua conseguinte expulsão servia para reforçar a política nacionalista brasileira, ao mesmo tempo em que aterrorizava as classes trabalhadoras, cercadas de ameaças policiais e de detenções temporárias que serviam unicamente para apaziguar as greves e as reivindicações sociais que explodiam por todas as esquinas da cidade. Dessa forma, as elites nacionais ocultavam as contradições surgidas no seio de um regime oligárquico que conduzia à modernização e negava a incorporação das massas ao processo de mudança social.

A expulsão mediante qualquer suspeita era uma rápida tática que servia de exemplo para toda a sociedade. O galego Vicente de Deus Belo foi expulso com apenas três meses de residência. Com seus 33 anos de idade, de profissão marítimo, havia chegado desde Nova York, sendo sócio, ali, 
da Associação de Marinheiros de Nova York. Por mais que alegasse que não havia tido tempo de se associar a nenhuma sociedade operária no Rio de Janeiro, os seus antecedentes e a sua nacionalidade já eram provas mais que suficientes para que os investigadores vigiassem os seus passos. De fato, no seu processo, das três testemunhas de acusação, dois eram investigadores policiais. Apesar da acusação reconhecer que Vicente de Deus era pouco conhecido na cidade, fizeram questão de mencionar a sua participação em centros anarquistas espanhóis e que o imigrante havia decidido imigrar para o Brasil com o único objetivo de divulgar a propaganda das idéias revolucionárias:

e tanto é assim, que logo ao desembarcar, Vicente foi para as associações e encarregou-se primeiramente da distribuição de boletins sediciosos e depois da propaganda de idéias, aconselhando a revolução, a desobediência às leis e autoridades, ataques e depredações. ${ }^{43}$

Portugueses e galegos, culpados ou inocentes, fizeram parte desse obscuro cenário das primeiras décadas do século XX. Empregados de padaria, assalariados, que se viam submersos na condição de marginalidade das suas classes. Saindo de um meio rural, de condições adversas ao contexto urbano carioca, esses imigrantes buscaram soluções para melhorar as condições de vida a que estavam submetidos. Alguns encontraram nos sindicatos uma base de apoio, onde puderam inclusive se destacar frente ao operariado nacional. Mas o fato de serem líderes ou participarem de greves e revoltas populares não significa que traziam as suas idéias da sociedade origem. Chegaram demasiado jovens, com pouca instrução e provenientes do meio rural. Os que se aderiram ao movimento sindical ou às revoltas populares podiam pertencer àquela classe de imigrantes que se vincularam mais à sociedade de acolhida e estavam mais desconformes com a situação precária em que viviam. Mesmo para aqueles que eram analfabetos ou careciam de conhecimentos acerca das doutrinas esquerdistas, não era difícil assimilá-las, já que era um período em que as idéias anarquistas ou socialistas começavam a ser trazidas pelos próprios brasileiros desde a Europa. Além disso, não se pode ignorar a efervescência dos movimentos operários no Estado de São Paulo e os freqüentes intercâmbios entre anarquistas paulistas e cariocas. A própria realidade, flagrada de adversidade, de problemas sociais e de exclusão política, uniam os trabalhadores nas greves, nos sindicatos ou nas revoltas populares. Outros tantos galegos, apesar de viverem os mesmos problemas, as mesmas exploraçōes por parte dos patrōes, preferiram não se envolver com questões 
políticas. Abandonar um projeto de imigração com vistas a um futuro próspero ou acusar o próprio patrão, que podia ser um patrício que lhe auxiliou na busca do primeiro emprego, não era tarefa das mais fáceis.

O Estado temia uma sublevação dos excluídos e os imigrantes temiam o terror do Estado. Os estrangeiros envolvidos em questóes políticas pouco podiam fazer- ou nada- contra a expulsão. Pertencer a determinados sindicatos era um "convite" para regressar a seu país. Nesse clima de tensão, muitos galegos foram expulsos injustamente, ainda que não nos caiba aqui o papel de juiz ou a confirmação da veracidade dos depoimentos dos processos. Os documentos esclarecem alguns pontos marcantes de uma parte da comunidade galega: a sua participação em sindicatos vinculados a sua classe trabalhadora, a sua não passividade frente às mudanças político-sociais brasileiras e a seu papel de explorador e de explorado. Junto com brasileiros, ex-escravos e outros imigrantes, principalmente com portugueses, estiveram presentes no cotidiano carioca, na configuração do seu espaço. Até mesmo aqueles que se mantiveram à margem, participaram desse processo, manifestando as suas posturas através de uma construção silenciosa do seu dia-a-dia, das limitações derivadas da sua própria condição de estrangeiro, convivendo entre a dualidade que dividia a imagem do imigrante trabalhador e a do indesejável.

\section{Notas e Referências}

1 RIO DE JANEIRO. Gazeta de Notícias, 24 de março de 1921, p.3.

2 Carlos Augusto ADDOR. A insurreição anarquista no Rio de Janeiro. Rio de Janeiro: Dois Pontos, 1986, p.85.

3 Fernando DEVOTO. Historia de la inmigración en la Argentina. Buenos Aires: Editorial Sudamericana, 2003, p.275.

4 Boris FAUSTO. Brasil, de colônia a democracia. Madrid: Alianza América, 1995. p.169.

5 Sobre a Revolta da Vacina, ver José Murilo de CARVALHO. Os bestializados. $O$ Rio de Janeiro e a República que não foi. São Paulo: Schwarcz, 1987.

6 RIO DE JANEIRO. A Notícia, 15 de Janeiro de 1909, p.2.

7 Lená Medeiros de MENEZES. Os indesejáveis: desclassificados da modernidade. Protesto, crime e expulsão na Capital Federal (1890-1930). Rio de Janeiro: EdUERJ, 1996, pp. 99-100.

8 Sheldom Leslie MARAM. Anarquistas, imigrantes e o movimento operário brasileiro, 1890-1920. Rio de Janeiro: Paz e Terra, 1979. Encontramos o mesmo argumento na obra de Everardo DIAS. Historia das lutas sociais no Brasil. São Paulo: Alfa-Ômega, 1977. 
9 Entrevista com M. M.B.. Dia 26 de setembro de 2000. Rio de Janeiro. (A identidade dos entrevistados foi preservada) Entrevista com J. A. Dia 20 de outubro de 2000. Rio de Janeiro.

Maria Cecília Velasco e CRUZ. "Tradiçôes negras na formação de um sindicato: Sociedade de Resistência dos Trabalhadores em Trapiche e Café, Rio de Janeiro, 1905-1930". Afro-Ásia, Salvador/CEAO, UFBA, 2000, pp.243-290.

13 Luiz Gustavo Nascimento de ALMEIDA. Estivadores do Rio de Janeiro. Um século de presença na história do movimento operário brasileiro. Rio de Janeiro: Topbooks, 2003, p.32.

14 John W. Foster DULLES. Anarquistas e comunistas no Brasil (1900-1935). Rio de Janeiro: Nova Fronteira, 1977, pp. 69-70

15 BRASIL. Arquivo Nacional (doravante A .N.). SPJ, pacotilha IJJ 138.

16 BRASIL. Arquivo Nacional. pacotilha IJJ 138.

17 BRASIL. Arquivo Nacional. SPJ, pacotilha IJJ7 138.

18 S. L. MARAM. Op. cit., p.19.

19 Edgar CARONE. A República Velha. Instituiçôes e classes sociais (1889-1930). Rio de Janeiro-São Paulo: Difel, 1978, pp.226-228 e 234.

20 John W. F.DULLES. Op. cit., p.58.

21 Entrevista com M. G. G. Dia 4 de novembro de 2003. Rio de Janeiro.

22 RIO DE JANEIRO. A Pátria, 11 de janeiro de 1921, p.3.

23 BRASIL. Arquivo Nacional. SPJ, pacotilha IJJ7 175.

24 BRASIL. Arquivo Nacional. SPJ, pacotilha IJJ 175.

25 BRASIL. Arquivo Nacional. SPJ, pacotilha IJJ 175.

26 Edgar RODRIGUES. Os companheiros 2. Rio de Janeiro: VJR, 1995, p. 156.

27 S. L. MARAM. Op. cit., p.58.

28 Edgar RODRIGUES. Os companheiros 4. Florianópolis: Insular, 1997, p. 53.

29 BRASIL Arquivo Nacional. SPJ, pacotilha IJJ 167.

30 L. M. de MENEZES. Op. cit., p.109.

31 Parece que a exploração da classe dos padeiros não se limitava só ao Brasil. Segundo Pilar CAGIAO, que estudou a emigração galega no Uruguai, na sua tese doutoral (Participación económico-social de los inmigrantes gallegos en Montevideo 1900-1970. Madrid, Universidad Complutense de Madrid, Departamento de Historia de América, 1990, p.162), o ramo das padarias também foi uma das atividades tradicionais dos imigrantes galegos em Montevidéu. Sobre a atividade sindical dos empregados de padaria, a autora comenta que: "el trabajo de la industria del pan, era tradicionalmente uno de los más duros y esclavos e indudablemente por ese motivo el gremio de los panaderos fue unos de los pioneros en las luchas sindicales integrando activamente desde 
1905 la Federación Obrera Regional Uruguay (Foru). Al año siguiente tuvo lugar una huelga de panaderos de verdadera relevancia, por encima de las que los trabajadores del sector habían practicado en 1901 y $1905 "$.

32 Juliana Barreto FARIAS, na sua dissertação de mestrado (Entre identidades e diásporas: Negros minas no Rio de Janeiro (1870-1930). Rio de Janeiro, Universidade Federal do Rio de Janeiro Programa de pós-graduação em Historia Comparada 2004) cita o manuscrito de João de Mattos, do ano de 1934, onde o mesmo relata a história dos padeiros escravos que queriam conquistar a sua liberdade e de padeiros livres que, em fins do século XIX e primeiras décadas do XX, lutavam por melhores condições de vida.

33 Id. Ibidem, p.40.

34 BRASIL. Arquivo Nacional. SPJ, pacotilha IJJ7 149.

35 L.M. de MENEZES. Op. cit., p.113.

36 BRASIL. Arquivo Nacional. SPJ, pacotilha IJJ7 146.

37 BRASIL. Arquivo Nacional. SPJ, pacotilha IJJ 146.

38 BRASIL. Arquivo Nacional. SPJ, pacotilha IJJ ${ }^{7} 146$.

39 RIO DE JANEIRO. Jornal do Brasil, 24 de março de 1921, p.9.

40 RIO DE JANEIRO. A Pátria, 28 de fevereiro de 1921, p.1.

41 RIO DE JANEIRO. A Pátria, 28 de fevereiro de 1921, p.1.

42 RIO DE JANEIRO. A Pátria, 18 de fevereiro de 1921, p.1.

43 BRASIL. Arquivo Nacional. SPJ, pacotilha IJJ 142. 